\title{
Classification tree to screen for the nursing diagnosis Ineffective airway clearance
}

Árvore de classificação para detecção do diagnóstico de enfermagem Desobstrução ineficaz de vias aéreas Árbol de clasificación para la detección del diagnóstico enfermero Limpieza ineficaz de las vías aéreas

\section{Daniel Bruno Resende Chaves', Lívia Maia Pascoal", Beatriz Amorim Beltrão', Marília Mendes Nunes', Tânia Alteniza Leandro', Viviane Martins da Silva', Marcos Venícios de Oliveira Lopes' \\ ' Universidade Federal do Ceará. Fortaleza, Ceará, Brazil. \\ "Universidade Federal do Maranhão, Center for Social Sciences, Health and Technology. Imperatriz, Maranhão, Brazil.}

\section{How to cite this article:}

Chaves DBR, Pascoal LM, Beltrão BA, Nunes MM, Leandro TA, Silva VM, et al.

Classification tree to screen for the nursing diagnosis Ineffective airway clearance.

Rev Bras Enferm [Internet]. 2018;71(5):2353-8. DOI: http://dx.doi.org/10.1590/0034-7167-2017-0085

\section{Submission: 03-21-2017_Approval: 10-01-2017}

\begin{abstract}
Objective: to identify the defining characteristics of Ineffective airway clearance with better predictive power using classification trees. Method: the predictive power of the defining characteristics of Ineffective airway clearance was evaluated based on classification trees generated from the data of 249 children with acute respiratory infection. Results: Ineffective cough and adventitious breath sounds were identified as the main defining characteristics when screening for Ineffective airway clearance in accordance with trees based on three different computational algorithms. Conclusion: Ineffective coughing and adventitious breath sounds had better predictive capacity for Ineffective airway clearance in the sample.
\end{abstract}

Descriptors: Nursing; Pediatric Nursing; Nursing Diagnosis; Respiratory Sign and Symptom; Children.

\section{RESUMO}

Objetivo: identificar as características definidoras de Desobstrução ineficaz de vias aéreas com melhor poder preditivo usando árvores de classificação. Método: o poder preditivo das características definidoras da Desobstrução ineficaz de vias aéreas foi avaliado com base em árvores de classificação geradas a partir dos dados de 249 crianças com infecção respiratória aguda. Resultados: tosse ineficaz e ruídos adventícios respiratórios foram identificados como as principais características definidoras na detecção de Desobstrução ineficaz de vias aéreas de acordo com as árvores, com base em três diferentes algoritmos computacionais. Conclusão: Tosse ineficaz e ruídos adventícios respiratórios tiveram melhor capacidade preditiva para Desobstrução ineficaz de vias aéreas na amostra.

Descritores: Enfermagem; Enfermagem Pediátrica; Diagnóstico de Enfermagem; Sinais e Sintomas; Crianças.

\section{RESUMEN}

Objetivo: identificar las características definitorias de la Limpieza ineficaz de las vías aéreas con un mejor poder predictivo utilizando árboles de clasificación. Método: el poder predictivo de las características definitorias de Limpieza ineficaz de las vías aéreas se evaluó basado en los árboles de clasificación generados a partir de los datos de 249 niños con infección respiratoria aguda. Resultados: La tos ineficaz y los sonidos respiratorios anormales se identificaron como las principales características definitorias cuando se realizaba una Limpieza ineficaz de las vías aéreas de acuerdo con los árboles en función de tres algoritmos computacionales diferentes. Conclusión: La tos ineficaz y los sonidos respiratorios anormales tienen una mejor capacidad predictiva para la Limpieza ineficaz de las vías aéreas en la muestra.

Descriptores: Enfermería; Enfermería Pediátrica; Diagnóstico de Enfermería; Signos y Síntomas; Niño. 


\section{INTRODUCTION}

Mistakes in the diagnostic inference can compromise care plans and consequently lead to unsatisfactory clinical outcomes for the patient, especially in complex clinical situations with multiple signs and symptoms or similar nursing diagnoses. Thus, strategies to identify a minimum set of clinical indicators associated with the specific clinical condition can improve the decision-making process. In this context, classification trees (CT) are graphical tools based on computational algorithms used to calculate conditional probabilities for a specific event (nursing diagnosis), according to the presence / absence of a minimum set of variables (defining characteristics).

The CT format presents leaf-nodes labeled with a value that correspond to the attribute of a class (presence / absence of a nursing diagnosis), and internal nodes represent descriptive attributes (presence / absence of defining characteristics). In the construction of a $C T$, the value of the class is determined by following a path from the root to the leaf, according to the values of the descriptive attributes in a category ${ }^{(1)}$. The branches of the base are considered terminal nodes, and they indicate that another division of the tree is not possible or reliable ${ }^{(2)}$.

However, a CT can have a large number of branches, which increases its complexity and decreases its capacity for generalization to new data sets. Therefore, pruning is necessary to build models of smaller trees ${ }^{(3)}$. Moreover, to generate models of CTs with satisfactory results in a short time, algorithms based on heuristic methods have been used ${ }^{(4)}$, including the Chi-square Automatic Interaction Detection (CHAID), the Classification and Regression Trees (CRT), and the Quick, Unbiased, Efficient Statistical Tree (QUEST).

The CHAID algorithm identifies the relationships among variables based on the Chi-square test. The CRT method, proposed by Breiman et al. ${ }^{(5)}$, divides the data so that the dependent variables are as homogeneous as possible. It is an automatic learning method of a classification tree with limited complexity. The QUEST algorithm, which is used for nominal dependent variables, is a rapid method, and it avoids biases that other methods present and favors predictors with multiple categories.

CT may be useful for diagnostic inferences and has been suggested as a possible strategy for clinically studying nursing diagnoses $^{(6)}$, especially in acute stages of a disease, because it allows a fast diagnostic decision to define specific nursing interventions based on robust computational algorithms. In this context, respiratory nursing diagnoses represent acute clinical conditions that require fast and precise identification because of the eminent risk of poor outcomes and death.

Respiratory nursing diagnoses (ND) have been studied in various populations, including children with acute respiratory infection (ARI) ${ }^{(7-9)}$. These infections are common in children, increasing airway secretions, and they are a clinical condition denominated by NANDA International (NANDA-I) as Ineffective airway clearance (IAC - 00031).

IAC is defined as the "inability to clear secretions or obstructions from the respiratory tract to maintain a clear airway"(10), and this clinical condition requires immediate attention, especially in children due to the risk of death or sequelae caused by the reduction of pulmonary ventilation and oxygen supply. In acute clinical conditions, the accurate identification of IAC allows immediate action, which minimizes the consequences of pulmonary hypoventilation.

\section{OBJECTIVE}

To identify the defining characteristics with the best predictive power in children with acute respiratory infection using classification trees for the screening of IAC.

\section{METHOD}

\section{Ethical aspects}

The ethics committee of the institutions approved the study, and the data collection began after the children's parents or guardians signed a consent form.

\section{Sample and inclusion and exclusion criteria}

A cross-sectional study was developed with a consecutive sample of 249 children younger than five years of age who were hospitalized with ARI from two pediatric hospitals located in Northeastern Brazil. Children were excluded if the following were present: intense crying with worsening cyanosis and cardiovascular or neurological diseases that may alter the clinical condition of the IAC.

\section{Data collection and organization}

Seven members of a research group dedicated to studying nursing diagnoses performed the data collection. The research team was trained to review and standardize respiratory assessments, and articles about clinical judgment in nursing diagnoses were discussed. A questionnaire based on operational definitions of each defining characteristic of IAC was developed in accordance with the literature. Moreover, two professors with experience in semiology and nursing diagnoses assessed this questionnaire.

\section{Analysis of results and statistics}

A panel of diagnosticians composed of two nurses with published research about diagnoses, interventions or nursing outcomes and clinical or teaching experience were selected to perform the diagnostic inference. They participated in a training to discuss the inference process of IAC, and their ability to correctly classify the presence or absence of the diagnosis was evaluated based on fictional clinical cases, as recommended by specialized literature ${ }^{(11)}$.

The presence or absence of IAC was determined by absolute agreement among the nurses. Disagreements were discussed between diagnosticians until consensus was reached, and an analysis of concordance was conducted using the Kappa coefficient adjusted by prevalence, which showed high agreement $(\mathrm{K}=0.775)^{(12)}$.

\section{Data analysis}

The descriptive analysis included frequencies, measurement of central tendency and dispersion. The classification trees were generated using an outcome variable (dependent), the consensual inference of IAC, and the defining characteristics as independent variables. CHAID, QUEST and CRT were the induction algorithms used in this study to develop the classification trees.

For the CHAID algorithm, the following basic parameters were utilized to generate CT: an estimation based on the likelihood ratio to obtain the Chi-square value; level of significance for node division and fusion of categories equal to 0.05; maximum number of 100 interactions and minimal alteration of the expected frequencies of the nodes of 0.05 for the estimation of the model. 
Bonferroni's method was used to correct the value of significance for the methods and the parameters of nodes' division and fusion.

For the CRT algorithm, the GINI measure was used as the parameter to reduce the impurities in the node division. This parameter is based on the square probabilities of cases (presence of defining characteristic) in each category of the dependent variable (IAC). The value of 0.001 was used as the minimum reduction of impurities in the node division. A 0.05 significance level for node divisions was established in the QUEST algorithm.

A maximum number of three levels was adopted for the CHAID algorithm, five levels were adopted for the CRT and QUEST algorithms. The minimum number of cases was 50 for a leaf node and 20 for internal nodes. The adoption of these parameters aimed to obtain the highest number of relationships among variables.

To avoid an over-adjustment of the model with the use of CRT and QUEST algorithms, tree pruning was utilized. This strategy allows the tree to be cut to obtain smaller nodes based on the specification of the maximum risk difference. This risk is expressed in typical errors, and its value was zero.
Cross-validation, which divided the sample into subsamples to generate several trees, assessed the structure of the trees. The risk of classification error was calculated by applying the tree to the subsample, and the result was compounded for a single tree with an estimated risk that was calculated based on the risks of all trees. The level of significance was 0.05 in all analyses.

\section{RESULTS}

The nursing diagnosis IAC was identified in $89.2 \%$ of the children. The most frequent respiratory diseases were pneumonia $(79.9 \%)$ and asthma (17.7\%). The median age of the children evaluated was 13.76 months $(\mathrm{IQ}=22.28)$ and the hospitalization time presented a median of one day $(I Q=1.00)$. Most of the sample was male $(55.8 \%)$. The tree generated by the CHAID method contained four nodes, including the characteristics ineffective cough and adventitious breath sounds. The correct percentage of prediction was $95.9 \%$ for the presence of IAC, $70.4 \%$ for the absence of diagnosis and $93.2 \%$ for overall correct classification.

Table 1 - Statistics of adjustment and prediction of the classification tree for Ineffective airway clearance generated by the Chi-square Automatic Interaction Detection growing method

\begin{tabular}{|c|c|c|c|c|c|c|}
\hline \multirow{2}{*}{ Node } & \multirow{2}{*}{$\begin{array}{c}\text { Absent } \\
\text { n (\%) }\end{array}$} & \multirow{2}{*}{$\begin{array}{c}\text { Present } \\
\mathbf{n}(\%)\end{array}$} & \multirow{2}{*}{$\begin{array}{c}\text { Total } \\
\text { n (\%) }\end{array}$} & \multirow{2}{*}{\multicolumn{2}{|c|}{ Primary independent variable }} & \multirow{2}{*}{$p$ value } \\
\hline & & & & & & \\
\hline 0 & $27(10.8)$ & $222(89.2)$ & $249(100.0)$ & & & \\
\hline 1 & 19 (67.9) & $9(32.1)$ & $28(11.2)$ & & fective cough & $<0.001$ \\
\hline 2 & $8(3.6)$ & $213(96.4)$ & $221(88.8)$ & & fective cough & $<0.001$ \\
\hline 3 & $8(2.1)$ & $30(78.9)$ & $38(15.3)$ & Adver & ious breath sounds & $<0.001$ \\
\hline 4 & $0(0.0)$ & $183(100.0)$ & $183(73.5)$ & Adver & ious breath sounds & $<0.001$ \\
\hline \multirow{2}{*}{ Classification } & & & \multicolumn{3}{|c|}{ Predicted } & \\
\hline & & & Present & Absent & Percent correct & \\
\hline \multirow[t]{3}{*}{ Observed } & Present & & 213 & 9 & $95.9 \%$ & \\
\hline & Absent & & 8 & 19 & $70.4 \%$ & \\
\hline & Overall pe & & $88.8 \%$ & $11.2 \%$ & $93.2 \%$ & \\
\hline \multirow[t]{2}{*}{ Risk } & & & Estimate & & Standard Error & \\
\hline & Cross-Valid & & 0.068 & & 0.016 & \\
\hline
\end{tabular}

Table 2 - Statistics of adjustment and prediction of the classification tree for Ineffective airway clearance generated by the Classification and Regression Trees growing method

\begin{tabular}{|c|c|c|c|c|c|c|}
\hline \multirow{2}{*}{ Node } & Absent & Present & \multirow{2}{*}{$\frac{\text { Total }}{\text { n (\%) }}$} & \multirow{2}{*}{\multicolumn{2}{|c|}{ Primary independent variable }} & \multirow{2}{*}{ Improvement } \\
\hline & n (\%) & n (\%) & & & & \\
\hline 0 & $27(10.8)$ & $222(89.2)$ & \multicolumn{3}{|l|}{$249(100.0)$} & \\
\hline 1 & $16(76.2)$ & $5(23.8)$ & $21(8.4)$ & \multicolumn{2}{|c|}{ Ineffective cough } & 0.092 \\
\hline 2 & $11(4.8)$ & $217(95.2)$ & $228(91.6)$ & \multicolumn{2}{|c|}{ Ineffective cough } & 0.092 \\
\hline 3 & $11(26.2)$ & $31(73.8)$ & $42(16.9)$ & \multicolumn{2}{|c|}{ Adventitious breath sounds } & 0.019 \\
\hline 4 & $0(0.0)$ & $186(100.0)$ & $186(74.7)$ & \multicolumn{2}{|c|}{ Adventitious breath sounds } & 0.019 \\
\hline \multirow{2}{*}{ Classification } & & & \multicolumn{3}{|c|}{ Predicted } & \\
\hline & & & Present & Absent & Percent correct & \\
\hline \multirow[t]{3}{*}{ Observed } & Present & & 217 & 5 & $97.7 \%$ & \\
\hline & Absent & & 11 & 16 & $59.3 \%$ & \\
\hline & Overall per & & $91.6 \%$ & $8.4 \%$ & $93.6 \%$ & \\
\hline \multirow[t]{2}{*}{ Risk } & & & Estimate & & Standard Error & \\
\hline & Cross-Valid & & 0.112 & & 0.020 & \\
\hline
\end{tabular}


Table 3 - Statistics of adjustment and prediction of the classification tree for Ineffective airway clearance generated by the Quick, Unbiased, Efficient Statistical Tree growing method

\begin{tabular}{|c|c|c|c|c|c|c|}
\hline \multirow{2}{*}{ Node } & \multirow{2}{*}{$\begin{array}{c}\text { Absent } \\
\mathbf{n}(\%) \\
\end{array}$} & \multirow{2}{*}{$\frac{\text { Present }}{\mathrm{n}(\%)}$} & \multirow{2}{*}{$\begin{array}{c}\text { Total } \\
\text { n (\%) } \\
\end{array}$} & \multirow{2}{*}{\multicolumn{2}{|c|}{ Primary independent variable }} & \multirow{2}{*}{$p$ value } \\
\hline & & & & & & \\
\hline 0 & $27(10.8)$ & $222(89.2)$ & $249(100.0)$ & & & \\
\hline 1 & $11(4.8)$ & 217 (95.2) & $228(91.6)$ & & fective cough & $<0.001$ \\
\hline 2 & $16(76.2)$ & $5(23.8)$ & $21(8.4)$ & & fective cough & $<0.001$ \\
\hline 3 & $0(0.0)$ & $186(100.0)$ & $186(74.7)$ & Advent & ious breath sounds & $<0.001$ \\
\hline 4 & $11(26.2)$ & $31(73.8)$ & $42(16.9)$ & Advent & ious breath sounds & $<0.001$ \\
\hline \multirow{2}{*}{ Classification } & & & \multicolumn{3}{|c|}{ Predicted } & \\
\hline & & & Present & Absent & Percent correct & \\
\hline \multirow[t]{3}{*}{ Observed } & Present & & 217 & 5 & $97.7 \%$ & \\
\hline & Absent & & 11 & 16 & $59.3 \%$ & \\
\hline & Overall per & & $91.6 \%$ & $8.4 \%$ & $93.6 \%$ & \\
\hline Risk & Cross-Valid & & $\begin{array}{c}\text { Estimate } \\
0.096\end{array}$ & & $\begin{array}{c}\text { Standard Error } \\
0.019\end{array}$ & \\
\hline
\end{tabular}

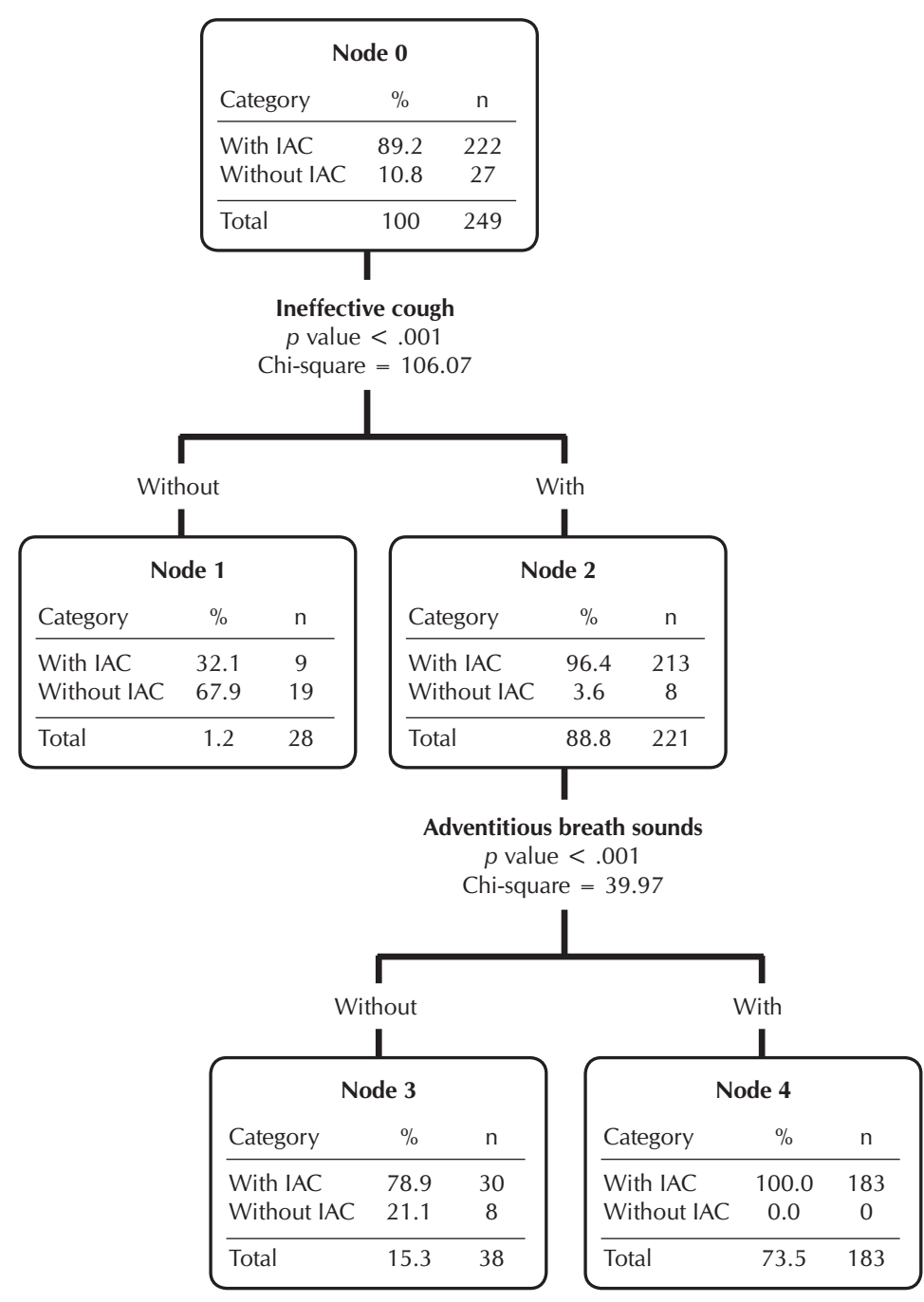

Figure 1 - Classification tree generated with defining characteristics for ineffective airway clearance using the Chi-square Automatic Interaction Detection growing method
Cross-validation showed a small classification error (Estimate: .068; 95\% Cl: .037 - .099) (Table 1).

The tree generated by the CRT method presented similar statistics to the previous method; however, the improvement observed in the nodes was relatively small, and although the overall percentage of correct classification and classification for the presence of IAC was somewhat better than the CHAID method, the correct classification of individuals without the diagnosis was $11.1 \%$ lower than that method. Additionally, the cross-validation error estimate was slightly worse than that with the CHAID method (Estimate: .112; 95\% Cl: .073 - .151) (Table 2). The QUEST growing method showed similar statistics to the CRT method; however, the QUEST method demonstrated a lower misclassification compared with CRT and a slightly higher misclassification than that obtained with the CHAID method (Estimate: .096; 95\% Cl: .059 - .133) (Table 3).

The results indicated that the tree developed with the CHAID growing method has a slightly better adjustment than the other methods. The $\mathrm{CT}$ based on the CHAID method has five nodes, including three terminal nodes. It presents two levels of profundity with two relevant DC: ineffective coughing and adventitious breath sounds (Figure 1). Ineffective cough was strongly related to the nursing diagnosis IAC because the probability of the diagnosis in the presence of this characteristic was .964 (96.4\%). The maximum probability (100\%) of IAC occurrence was found in comparing the two DC.

\section{DISCUSSION}

In this study, most children presented ineffective airway clearance. Previous studies have found various prevalence rates of this nursing diagnosis. Andrade et 
al. ${ }^{(13)}$, when studying IAC in children with acute respiratory infection, identified that $71.9 \%$ of the sample manifested this diagnosis. Similarly, a study in a prospective cohort of children with ARI found IAC in $91.9 \%$ of the sample on the first day of follow-up ${ }^{(8)}$.

The high prevalence of IAC may be related to the physiopathology presented by the population included in this study and other samples cited in studies. Asthma, which was one of the medical diagnoses most frequently found in this study, is characterized by respiratory symptoms including cough, dyspnea, pulmonary sounds, and cyanosis ${ }^{(14)}$. These clinical indicators represent alterations in the respiratory tract of a child and can lead to the occurrence of IAC.

CTs generated in this research to assist in the inference of the cited diagnosis presented similarity regarding the presence of the DC ineffective cough and adventitious breath sounds. These characteristics were representative of IAC due to their relevance, individually and together, to the diagnosis.

In the literature, no studies utilized CT to identify the defining characteristics of IAC; therefore, we were unable to make comparisons with findings in this research. However, certain authors highlighted the importance of ineffective cough and adventitious breath sounds in IAC. These DCs were found mostly in children with ARI, who were similar to the sample in the study by Andrade et al. ${ }^{(13)}$. These authors evaluated the clinical spectrum of the indicators of IAC and found a moderate spectrum of adventitious breath sounds and mild spectrum of ineffective cough in most children.

Ineffective cough, especially in children with ARI, is an important sign of clinical compromise. Children have immature respiratory tracts and narrow airway, creating difficulty in the respiratory system to respond to secretions and consequent mobilization by the mechanism of cough ${ }^{(15)}$. Therefore, the secretions are retained in the airway, endangering the child to clinical decline.

In this study, this DC was strongly related to IAC. The probability of ND was higher than $95 \%$ in all generated trees in children with ineffective cough. Furthermore, ineffective cough may concomitantly occur with another DC or trigger the occurrence of them. For example, a respiratory infectious process leads to the accumulation of secretion in the airways if the cough is ineffective. Secretions cause resistance in the airflow, changing the sound produced during respiration, and children may present adventitious breath sounds.

The relevance of adventitious breath sounds is emphasized in the findings of Mendes Cavalcante, Lopes and Lima ${ }^{(16)}$ on the accuracy of the DCs of IAC in asthmatic children. These authors suggest that adventitious breath sounds are the most frequent DC and have a high sensitivity to detect IAC. It is known that sensitivity is the correct identification of the presence of a clinical indicator in patients with the diagnosis ${ }^{(11)}$. In children with ARI, a clinical indicator with high sensitivity can be useful to advise nurses about the possible manifestation of a respiratory nursing diagnosis and the necessity of collecting new information to base the diagnostic decision.

\section{Limitations of the study}

In this study, the characteristics were considered dichotomous variables; however, in practice, we observed that these variables manifest in various ways. This limitation was considered important in the diagnostic inference by the raters because, in some specific cases, questions about the presence of the diagnosis in a mild clinical spectrum generated doubts. This relationship needs to be further studied by applying the trees in clinical practice and submitting them to studies of clinical validation in children with acute respiratory infection and other groups. Considering that studies with a cross-sectional design do not allow the evaluation of cause-effect relationships, further studies, with a longitudinal design, are encouraged to allow this evaluation. In addition, the lack of studies with a similar approach to this study limited the comparison of the results.

\section{Conclusion and contributions for nursing practice}

Ineffective coughing and adventitious breath sounds had better predictive capacity for IAC because they remained present in the generated classification trees. The tree developed with the CHAID growing method has a slightly better adjustment than the other methods. Methods that analyze variables in group, with an emphasis on graphical tools to assist diagnostic decisions (classification tree), can contribute to a faster diagnostic inference process in clinical practice. Additionally, these tools can be useful to present important indicators of a diagnosis for nursing students.

Classification trees can make the diagnostic inference of IAC more accurate. The results of this study are useful for fast screening of IAC among children with ARI, and the correct identification of this diagnosis will help apply more resolute interventions and achieve more positive outcomes.

\section{FUNDING}

We thank the Foundation for Research and Scientific and Technological Development of Maranhão (FAPEMA) for the financial support provided.

\section{REFERENCES}

1. Stiglic G, Kocbek S, Pernek I, Kokol P. Comprehensive Decision tree models in bioinformatics. PLoS ONE[Internet]. 2012[cited 2015 Nov 30];7(3):e33812. Available from: http://journals.plos.org/plosone/article?id=10.1371/journal.pone.0033812

2. Demir B, Kumkale GT. Individual differences in willingness to become an organ donor: a decision tree approach to reasoned action. Pers Individ Dif[Internet]. 2013[cited 2015 Dec 9];55(1):63-9. Available from: http://www.sciencedirect.com/science/ article/pii/S019188691300069X

3. Cho JH, Kurup PU. Decision tree approach for classification and dimensionality reduction of electronic nose data. Sens Actuators 
B Chem[Internet]. 2011[cited 2016 Jan 13];160(1):542-48. Available from: http://www.sciencedirect.com/science/article/pii/ S0925400511007507

4. Basgalupp MP. LEGAL-Tree: um algoritmo genético multi-objetivo para indução de árvores de decisão[Tese]. Instituto de Ciências Matemáticas e de Computação. Universidade de São Paulo, Brasil; 2010.

5. Breiman L, Friedman JH, Olshen RA, Stone CJ. Classification and Regression Trees. Belmont: Wadsworth; 1984.

6. Lopes MVO, Silva VM, Araújo TL. Validação de diagnósticos de enfermagem: desafios e alternativas. Rev Bras Enferm[Internet]. 2013[cited 2017 Aug 11];66(5):649-55. Available from http://www.scielo.br/pdf/reben/v66n5/02.pdf

7. Andrade LZC, Chaves DBR, Silva VM, Beltrão BA, Lopes MVO. Respiratory nursing diagnoses for children with acute respiratory infection. Acta Paul Enferm[Internet]. 2012[cited 2015 Dec 13];25(5):713-20. Available from: http://www.scielo.br/pdf/ape/v25n5/ en_11.pdf

8. Pascoal LM, Beltrão BA, Chaves DBR, Lopes MVO, Silva VM, Sousa VEC, et al. Estudio longitudinal de los diagnósticos de enfermería respiratorios en niños con infección respiratoria aguda. Enferm Clín[Internet]. 2012[cited 2016 Jan 11];22(5):255-60. Available from: http://www.sciencedirect.com/science/article/pii/S1130862112001027

9. Monteiro FPM, Silva VM, Lopes MVO. Diagnósticos de enfermagem identificados em crianças com infecção respiratória aguda. Rev Eletr Enferm[Internet]. 2006[cited 2015 Dec 7];8(2):213-21. Available from: https://www.fen.ufg.br/fen_revista/revista8_2/ v8n2a06.htm

10. Herdman TH, Kamitsuru S, (Ed.). Nursing diagnoses: definitions and classification 2015 - 2017. Oxford, UK: Wiley - Blackwell; 2014.

11. Lopes MVO, Silva VM, Araújo TL. Methods for establishing the accuracy of clinical indicators in predicting nursing diagnoses. Int J Nurs Knowl[Internet]. 2012[cited 2016 Jan 5];23(3):134-9. Available from: http://onlinelibrary.wiley.com/wol1/ doi/10.1111/j.2047-3095.2012.01213.x/full

12. Kestenbaum B. Epidemiology and biostatistics: an introduction to clinical research. London: Springer; 2009.

13. Andrade LZC, Silva VM, Lopes MVO, Chaves DB, Távora RC. Ineffective airway clearance: prevalence and spectrum of its clinical indicators. Acta Paul Enferm[Internet]. 2014[cited 2016 Jan 10];27(4):319-25. Available from: http://www.scielo.br/pdf/ape/v27n4/ en 1982-0194-ape-027-004-0319.pdf

14. Nakaie CMA, Cardieri JMA. Asma. In: Grisi SJFE, Escobar AMU, (Org.). Prática pediátrica. 2 ed. São Paulo: Athene; 2007.

15. West JB. Fisiologia Respiratória: princípios básicos. 8 ed. Porto Alegre: Artmed; 2010.

16. Mendes LC, Cavalcante JCB, Lopes MVO, Lima LHO. Ineffective airway clearance in children with asthma: a descriptive study[Internet]. Texto Contexto Enferm[Internet]. 2012[cited 2015 Dec 19];21(2):371-8. Available from: http://www.scielo.br/pdf/ tce/v21n2/en_a15v21n2.pdf 